Judith St. John states in the preface that the "scope" of the present catalogue "is generally restricted to children's books published in England before 1910", but it also includes other books that children "have read and enjoyed, school books for young people past the elementary level" that are "of interest to educationists ... who have used the collection" and "original editions of books adopted by English-speaking children". Also included in the present volume are some books, published after 1910, by authors whose careers were well-established before then.

Books are arranged alphabetically within the following classification system: Aesop and other fabulists; Myths and legendary heroes; Nursery stories and fairy tales; Poetry, verses, and rhymes; Nursery rhymes and alphabets; Books of instruction; The Bible and books of religious instruction; Biography and history; Travel and geography; Natural Science; Games and pastimes; Stories - before 1850; Stories - 1850 and after; Keepsakes and miscellanies; Movable and toy books; Almanacs and birthday books. Although this arrangement is similar to the one used in Volume I, two sections, however, have been omitted, namely, Periodicals and annuals and Penny dreadfuls. An appendix gives a chronological list of editions from 1476 to 1799. Lists of Illustrators and engravers and Publishers, booksellers and printers that appeared in appendixes in Volume I have been omitted in Volume II. The index includes authors, titles, series, editors and translators. The second volume is paged continuously with the first volume, and is set in computerized type. The illustrations include black and white head-and tailpieces, and a coloured frontispiece of Edgar Osborne.

Cataloguing procedures have been followed. Title-pages have been transcribed in full, except for minor references. Descriptive annotations accompany the entries and some biographical information is also provided. Volume II is a worthy successor to Volume I, and should prove a valuable aid to researchers in the field of children's literature.

Irene E. Aubrey

(Ms. Aubrey is Children's Literature Librarian/Consultant at the National Library of Canada.)

\title{
MINES OF INFORMATION
}

A Survey of Canadian Mining History. [By] W. George Richardson. [Montreal]: The Canadian Institute of Mining and Metallurgy, 1974. (Special Volume 14) [5], iii, 115 p., paper, $\$ 10.00$.

Canadian Engineering Heritage Record, Catalogue 1972-74. Ottawa: Department of Indian and Northern Affairs, 1976. Bilingual text, English 41, [2] p., French 43, [2] p., paper, free (Canadian Engineering Heritage Record, 365 Laurier Ave., W., 16th floor, Ottawa, Ontario, K1A 0H4).

An earlier version of this joint review contained an extensive chronicle of the sins, error, omissions, and general failings of the Canadian Engineering Heritage Record Catalogue. Unfortunately, this left very little room for the other book, a very worthwhile and useful tool. 
The Canadian Engineering Heritage Record is a joint programme sponsored by the Department of Indian and Northern Affairs and the Engineering Institute of Canada. Its purpose is to document "the tangible remains of Canada's engineering, technological and industrial heritage "(p. 1). It is essentially a volunteer programme based on the premise that engineers care enough about their history, and that given a place for such reports they would photograph, draw, research, and write worthwhile reports to be filed in a central repository chronicling Canadian engineering history. It has not worked. Much of the information in the reports is scanty and seldom documented. The reports are accepted uncritically, given a number, and filed. With rare exception, the reports, and their short catalogue descriptions, show little or no understanding of how historical research is carried on and what historians actually do. The catalogue lists, by province, the objects reported and gives brief and generally uninformative comments, as well as a rating, sometimes misleading, on the "precision and depth of the available information"(p.1). Most of the reports are in the lowest category.

It is rather difficult to say who would find the catalogue useful. It is an excellent example to show how not to prepare a catalogue. If you are professionally involved with engineering history you might want to be aware of this programme and publication, but the reviewer is not sure why. It is not totally useless, but then no books are, and you have already paid for it with your taxes.

Noteworthy works in the history of technology in Canada are few and far between. Professor Richardson's A Survey of Canadian Mining History, is one of the few. It is not a large book, less than 125 pages of doublespaced typescript. Do not misled by size; it is very useful, in fact, an indispensable working tool for those starting a research project in the history of Canadian mining.

The book is well organized and easy to use. The first part is a brief summary of Canadian mining history; an annotated bibliography is the second and larger part. Both are divided into the following sections: Canada in general; the Maritime Provinces; Quebec; Ontario; The Prairie Provinces; British Columbia; Yukon and Northwest Territories. Each of the above is treated under five categories: general; precious metals; base metals; miscellaneous; unpublished documents.

Although some might wish to criticize the organization, the bibliography works. The reviewer has found it useful since it was completed in 1973 as an M.A. thesis, at the Institute for the History and Philosophy of Science and Technology, University of Toronto.

Each bibliographic entry contains publication data, plus mention of length, illustrations, index, and use of footnotes and bibliography. This is followed by a short analysis, usually two to five lines, and a numerical rating ranging from zero to five. A book which rates a zero "is not useful and is only included because the title might otherwise mislead the reader "(p. 6). The highest rating, five, is reserved for a "complete treatment of the subject, including adequate descriptions of the technology and a full analysis of its various effects, utilizing original sources fully cited and illustrated. It is accurate, well balanced, objective and scholarly "(p. 6). Naturally, the awarding of an honour such as a "five" rating is somewhat subjective process, but the ratings are a useful preliminary guide. Students, particularly those philosophically committed to using no more than three books per essay, will find this an invaluable aid in selecting the favoured three. Other less useful works can then be cited in the student's biblio- 
graphy but not read. Serious historians, doring detailed research, will naturally go beyond the works mentioned by Richardson. But to criticize the work for failing to anticipate every move of the expert would be unjust.

There are very few experts in Canadian mining history. There are many people - students, historians, and others - who would find reading and research in this area stimulating, but they do not know where to start. Professor Richardson has shown them and, in doing so, has filled a serious bibliographic need.

\title{
Norman R. Ball
}

(Mr. Ball is an historian of Canadian technology. A graduate of both McMaster University and the University of Toronto, he is presently spending his spare moments completing a doctoral dissertation: The Technology of Settlement in Upper Canada Prior to 1840. Mr. Ball has published and spoken widely on the subject of technology in Canada, and is one of the editors of Let Us Be Honest and Modest: Technology and Society In Canadian History (O.U.P., 1974). At the present time he is Science and Technology Archivist, Manuscript Division, Public Archives of Canada, Ottawa.)

An Index of Names in "Lunenburgh or the Old Eastern District" by Jacob Farrand Pringle, published in 1890, compiled by Lyall Manson. Cornwall: The Stormont, Dundas and Glengarry Historical Society, 1975. vi, 50 p., paper, $\$ 2.50$.

Researchers in U.E.L. lore and genealogy have reason to thank Mr. Manson and his team for this useful index. Unfortunately, others will not be so thankful. Inclusion of places, military units, battles, forts, organizations, and so on, would have made the index more complete, would have meant relatively little more work, and would have given it much wider appeal to others such as military historians, geographers, and persons interested in the development of the area.

This reviewer feels that the work of all those who had a hand in compiling the index should have been acknowledged by including their names. Seeing their names in print might encourage several boys and girls to become historians, or at the least, to join the Stormont, Dundas and Glengarry Historical Society.

It is generally recognized by indexers that, when several people have the identical surname, it is not necessary to repeat the surname for each entry. Double indents can be used to avoid confusion when one entry takes more than one line, e.g.

\author{
Anderson, John, 71, 336 \\ Joseph, 38, 48, 54, 56, 60, \\ $65,66,75,77,180,181$, \\ 204,227 \\ M., 281 \\ M. J., 245,284 \\ Michael, 279
}

